\title{
Assessment of immunohistochemical Expression of HER2\Neu and BRCA1 in Colorectal Tumors and it's Correlation with Clinicopathological Variables
}

\author{
Dr. Sarah Saad Bonyan( M.B.Ch. B), (M.Sc. path.), Pathology Department, Al- \\ Hussain (Al-Nasrya) teaching hospital. \\ Dr. Akeel Saad Bonyan( M.B.Ch. B) , (D.G.S)Diploma of general surgery , Al- \\ Hussain(Al-Nasrya) teaching hospital. \\ Dr. Alaa Ghani Hussain(M.B.Ch.B), (F.I.C.M.S. Path), Professor, Al- Nahrain \\ University, College of Medicine.
}

\begin{abstract}
:
Background: HER2 \neu and BRCA1 expression in tumors is consider as a important prognostic marker in relation to the use of adjuvant therapy specially in a patients with worse prognosis in which that result in improvement in their survival. this research was done to assess the HER2 Ineu and BRCA1 immunohistochemical expression in colorectal tumors in correlation with some clinicopathological parameters.

Methods: in this study(which was done retrospectively), A 44 cases include22 benign colonic lesions and 22 colonic adenocarcinoma in addition 6 normal resection (non tumors) margin were used as a control group, paraffin embedded archival materials from this cases were collected for the period between Nov 2015- July 2016.the expression of 2 markers (HER2/neu and BRCA1)were assessed and then were correlated with different clinicopathological parameters .

Results: the immunohistochemical expression of HER2।neu was $(45 \%)$ of CRC, in $(27 \%)$ of colorectal polyps and in (4) out of (6) non-neoplastic colonic tissues.

HER2 Ineu was expressed more frequently in the colon in about (46\%), in female (39\%), in the age group of more than 40 years $(43 \%)$, in well differentiated adenocarcinoma (67\%), in non mucinous adenocarcinoma (90\%), in T2 (54\%) and the tumor size of more than $4 \mathrm{~cm}(66 \%)$ although the results were statistically not significant..

BRCA1 immunostaining was found in $(6 \%)$ of colorectal tumor and there were (14\%) positive cases of colorectal polyps, the result was statistically not significant.

BRCA1 expressed more frequently in the colon (20\%), in male $(8 \%)$ and age group of more than 40 years $(10 \%)$ the results were statistically not significant. there was no difference in BRCA1 expression between tumor size of more or less than $4 \mathrm{~cm}$.

Conclusions: In this study researchers concluded that expression of HER2 2 neu in colorectal tumors (benign and malignant) is not infrequent phenomena, HER2 \neu expression was obviously increased in non-neoplastic tissues and adenoma, Low expression of BRCA1 in colorectal tumors and no significant correlation of BRCA1 expression in relation to the clinicopathological parameter (age, gender, tumors types, site and size).
\end{abstract}

Key words: Immunohistochemical Expression-HER2 Ineu , BRCA1, Colorectal Tumors 
ISSN (Print):1992-92 18, ISSN (Online):1992-92 18

DOI: https://doi.org/10.32792/utq/utjmed/19/1/9

\section{Introduction}

one of the most common malignancies worlds wide is Colorectal carcinoma (CRC), it regarded as fifth most common form of cancer in the United States and in the Western world it consider the second leading cause of cancer-related death ${ }^{(1,2)}$ in Iraq, it was noticed there was a steady rise in CRC especially over the last two decades the percentage of total cases of colorectal carcinoma was $4.45 \%$ of all malignancies for both genders and among the leading causes of death from cancer it was the seventh ${ }^{(3)}$.

HER2 Ineu and BRCA1expression in tumors is consider as a important prognostic marker in relation to the use of adjuvant therapy specially in a patients with worse prognosis in which that result in improvement in their survival for that reason HER2 1 neu and BRCA1 have been studied in many tumors $(4,5)$.

The role of HER2 Ineu and BRCA1 has been recognized in breast carcinoma and is consider a routine tests for breast cancer patients especially with the introduction of effective therapy targeting HER2, Trastuzumab was the most important one, but There are only a few studies about HER2 Ineu and BRCA1expression in colorectal tumor. There are only few studies with great controversy and lack conclusive result regarding the HER2 \neu and BRCA1 real prognostic value in colorectal tumor in addition to their location on the long arm of chromosome 17 in close proximity gave an interest in investigating these markers together. ${ }^{(6)}$

The proto-oncogene HER2 \neu (CerbB-2) has been localized to chromosome $17 \mathrm{q}$ and encodes a transmembrane tyrosine kinase growth factor receptor ${ }^{(7)}$.

HER2/neu directed therapy:- The use of an anti-HER2 monoclonal antibody (Herceptin) treatment of the patients has been shown to augment the effects of chemotherapy, to reduce tumor volume and to increase survival in $_{(8)}$ primary and metastatic breast cancer

The use of HER2/neu directed therapy in breast cancer with successful result has lead to evaluate the protein expression and gene amplification in many tumors of the body, colorectal cancer among others.it has been shown that Herceptin inhibit colony formation of the HCA-7 colon cancer cell line and HCA-7 tumor xenografts ${ }^{(9)}$.

BRCA1:-It is tumor suppressor located on long arm of chromosome 17 (10), which maintains genomic integrity to prevent uncontrolled proliferation. (11), BRCA1 mutations Carriers have increased risk of developing breast cancer about 20-fold higher than the general population. Many cases of high-grade sporadic breast and ovarian cancers reported reduced BRCA1 expression that's implying the role of BRCA1 in sporadic breast and ovarian cancer as well ${ }^{(12)}$. Mutations in BRCA1 are also associated with other cancers, particularly "hormoneresponsive tumor types" like the uterine, cervical, fallopian tube, testicular and others like colonic cancers. ${ }^{(13,14)}$. In the past Several studies had been reported an increased risk of colorectal cancer in patients with BRCA1 or BRCA2 germ-line mutations ${ }^{(5,14,15)}$. It has been shown that there is association between shorter survival in colorectal cancer 
ISSN (Print):1992-92 18, ISSN (Online):1992-92 18

DOI: https://doi.org/10.32792/utq/utjmed/19/1/9

and loss of heterozygosity at the BRCA1 gene locus ${ }^{(5)}$.

This study was done to assess the immunohistochemical expression of HER2 \neu and BRCA1 in colorectal tumors (carcinoma and polyps) in correlation with some clinicopathological parameters.

\section{Patients, Material and Methods :}

Tissue Sample: - In this study (retrospective study) a total of (44) cases of colorectal tumors of which (22) cases CRC and (22) cases colorectal polyps were taken .Of these (44) cases, (30) cases were colectomy and (14) cases were tissue biopsy. In addition to these cases there were (6) cases of normal (non tumorous) resection margin as a control.

A formalin fixed, paraffin-embedded tissues were retrieved from the archived files of the department" of pathology of Al-Kadhimiya teaching hospital,Al-Nasrya(Alhussain)teaching hospital and Gastrointestinal intestinal tract center for the period between Nov 2015- July 2016.From the available histological reports Clinicopathological parameters was obtained .

Three sections of $5 \mu \mathrm{m}$ thickness were taken for each case; one section was stained with $(\mathrm{H} \& \mathrm{E})$, and the other was stained immunohistochemically with HER2\neu and BRCA1 tumor markers.

Immunohistochemical staining:

The streptavidin -biotin is the method has been used .

The Sections $(5 \mu \mathrm{m})$ were cut from paraffin blocks and they were deparaffinized in xylol and rehydrated through descending alcohol series.
After retrival of the slides in the retrival solution in water bath at $950 \mathrm{C}$ for 40 minutes for HER2/neu and for 20 minute for BRCA1.then endogenous peroxidase was inactivated by incubating the section with $3 \%$ hydrogen peroxide for 10 minutes, The sections were incubated with primary antibody over night at $40 \mathrm{C}$ the antibodies used were monoclonal mouse antibody anti-human BRCA1 (Dako) at 1:50 dilution and the other is polyclonal rabbit antihuman HER2/neu oncoprotein (Dako) at 1:250 dilution.

Sections then were incubated for 30 minutes with biotinylated anti-mouse immunoglobulin (Dako).Then strepavidin conjugated to horseradish peroxidase was used, then washing with phosphate buffer solution .Then the section were incubated with diaminobenzidine substrate for 10 minutes . The section were rinsed with distilled water and counter stained with Mayr's haematoxyllin.

for each staining run negative and positive control slides were included .The negative control slides in the absence of primary antibody and the Positive control were invasive breast cancer for HER2lneu and the ovarian cancer for BRCA1 .

Interpretation of the results of staining characteristic:

The positive reactivity is indicated by the presence of brown reaction product of more than $10 \%$ of tumor hcells at the target antigen site.

Counter stain will be pale to dark blue coloration of the cell nuclei.

The pattern of Staining for HER 12neu: cytoplasm or membranecytoplasm (16) and for BRCA1: cytoplasm or nuclear -cytoplasm. 


\section{ISSN (Print):1992-92 18, ISSN (Online):1992-92 18}

DOI: https://doi.org/10.32792/utq/utjmed/19/1/9

The quantity of the immunostaining was evaluated as follows ${ }^{(17,18)}$ :

_ Less than $10 \%$ of tumor cell immunostaining.

$+\quad 10-40 \%$ of tumor cells immunostaining.

$+41-70 \%$ o of tumor cells immunostaining.

$+++>70 \%$ of tumor cells immunostaining.

The positive result classified as focal and diffuse.

Focal:-in which clusters of positive cells where seen in some areas of the tumor but other region where negative Diffuse: - in which isolated and/or clusters of positive cells where seen throughout most areas of the tumor.

In table 1, the detailed data of 44 specimen are shown.

Table 1: Patients characters

\begin{tabular}{|c|c|c|c|c|c|}
\hline \multirow{2}{*}{\multicolumn{2}{|c|}{$\begin{array}{l}\text { Clinicopathological } \\
\text { parameters }\end{array}$}} & \multicolumn{2}{|c|}{ Benign } & \multicolumn{2}{|c|}{ Malignant } \\
\hline & & \multirow{2}{*}{$\begin{array}{l}\text { Number } \\
16 / 23\end{array}$} & \multirow{2}{*}{$\begin{array}{l}\text { Percent } \% \\
70\end{array}$} & \multirow{2}{*}{$\begin{array}{l}\text { Number } \\
7 / 23\end{array}$} & \multirow{2}{*}{$\begin{array}{l}\text { Percent \% } \\
30\end{array}$} \\
\hline Age in years & $\leq 40$ & & & & \\
\hline & $>40$ & $4 / 21$ & 19 & $17 / 21$ & 81 \\
\hline \multirow[t]{2}{*}{ Sex } & Male & $14 / 22$ & 64 & $12 / 22$ & 55 \\
\hline & Female & $8 / 22$ & 36 & $10 / 22$ & 45 \\
\hline \multirow[t]{2}{*}{ Tumor site } & colon & $14 / 26$ & 54 & $12 / 26$ & 45 \\
\hline & Rectum & $8 / 18$ & 44 & $10 / 18$ & 56 \\
\hline \multirow{2}{*}{$\begin{array}{l}\text { Tumor size in } \\
\text { cm }\end{array}$} & $\leq 4$ & $10 / 15$ & 67 & $5 / 15$ & 33 \\
\hline & $>4$ & $8 / 29$ & 8 & $21 / 29$ & 72 \\
\hline \multirow[t]{2}{*}{ Tumor type } & Mucinous & & & $3 / 22$ & 14 \\
\hline & Non mucinous & & & $19 / 22$ & 86 \\
\hline \multirow{8}{*}{$\begin{array}{l}\text { Histological } \\
\text { type }\end{array}$} & TA & $8 / 22$ & 36 & & \\
\hline & TVA & $2 / 22$ & 9 & & \\
\hline & VA & $3 / 22$ & 14 & & \\
\hline & JRP & $2 / 22$ & 9 & & \\
\hline & Hyper.P & $2 / 22$ & 9 & & \\
\hline & Inf.polyp & $4 / 22$ & 18 & & \\
\hline & $\begin{array}{l}\text { Hamartomatous } \\
\text { polyp }\end{array}$ & $1 / 22$ & 5 & & \\
\hline & $\mathrm{AC}$ & & & $22 / 22$ & 100 \\
\hline \multirow[t]{3}{*}{ Tumor grade } & WD & & & $3 / 22$ & 14 \\
\hline & MD & & & $9 / 22$ & 41 \\
\hline & PD & & & $10 / 22$ & 45 \\
\hline Tumor depth & $\mathrm{T} 1$ & & & $5 / 22$ & 22 \\
\hline
\end{tabular}

Statistical analysis was done using the SPSS 10.01(statistical package for social sciences).

Two-tailed t-test, chi square distribution test and ANOVA test, were used. $(\mathrm{P})$ values of $\leq 0.05$, were considered statistically significant Results:

There were (26) cases males and (18) cases females and males: females' ratio is 1.4

The mean age of the cases was $44.42 \pm$ 2.53 years, with a range of (3-87) years.

The mean size of the cases (Mean \pm SEM) was $2.59 \pm 0.54 \mathrm{~cm}$ with the range of $(0.2-21) \mathrm{cm}$. 
ISSN (Print):1992-92 18, ISSN (Online):1992-92 18

DOI: https://doi.org/10.32792/utq/utjmed/19/1/9

\begin{tabular}{|l|l|l|l|l|}
\hline T2 & & $13 / 22$ & $\mathbf{5 9}$ \\
\hline T3 & & $\mathbf{4} / 22$ & $\mathbf{1 8}$ \\
\hline
\end{tabular}

Immunohistochemical study:

HER2/neu over expression:

HER2 Ineu immunostaining was clearly evident as brown membrane and cytoplasmic staining or brown cytoplasmic staining.

Positive staining was localized in the membrane and cytoplasm in (15) cases $(93 \%)$ and cytoplasmic in (1) case (7\%) of the cases of colorectal tumors (benign and malignant).

The quantity of the HER2\neu immunostaining was +++ in (13) cases of colorectal tumor $(81 \%)$ and ++ in (3) cases $(19 \%)$

Table 2: correlation between clinicopathological parameters:
Pattern of staining was variable; it was diffuse in (15) cases (93\%) and focal in (1) case $(7 \%)$ of colorectal tumors (benign and malignant).

Correlation between the expression of HER2/neu and various 2 clinicopathological parameters are shown in table 2 .

\begin{tabular}{|c|c|c|c|c|}
\hline \multicolumn{2}{|l|}{ The variable } & $\begin{array}{l}\text { Positive } \\
\text { HER2/neu }\end{array}$ & $\begin{array}{l}\text { negative } \\
\text { HER2/neu }\end{array}$ & $P$ value \\
\hline \multirow[t]{3}{*}{ Groups } & Normal & $4 / 6(67 \%)$ & $2 / 6(33 \%)$ & \multirow[t]{3}{*}{0.174} \\
\hline & Benign & $6 / 22(27 \%)$ & $16 / 22(73 \%)$ & \\
\hline & Malignant & $10 / 22(45 \%)$ & $12 / 22(55 \%)$ & \\
\hline \multirow[t]{2}{*}{ Age } & $\leq 40$ & $7 / 23(30 \%)$ & $16 / 23(70 \%)$ & \multirow[t]{2}{*}{0.174} \\
\hline & $>40$ & $9 / 21(43 \%)$ & $12 / 21(57 \%)$ & \\
\hline \multirow[t]{2}{*}{ Sex } & Male & $9 / 26(35 \%)$ & $17 / 26(65 \%)$ & \multirow[t]{2}{*}{0.639} \\
\hline & Female & $7 / 18(39 \%)$ & $11 / 18(61 \%)$ & \\
\hline \multirow[t]{2}{*}{ Tumor site } & colon & $12 / 26(46 \%)$ & $14 / 26(54 \%)$ & \multirow[t]{2}{*}{0.174} \\
\hline & Rectum & $4 / 18(22 \%)$ & $14 / 18(78 \%)$ & \\
\hline \multirow[t]{2}{*}{ Tumor size in $\mathrm{cm}$} & $\leq 4$ & $6 / 15(40 \%)$ & $9 / 15(60 \%)$ & \multirow[t]{2}{*}{0.174} \\
\hline & $>4$ & $19 / 29(66 \%)$ & $10 / 29(34 \%)$ & \\
\hline \multirow[t]{2}{*}{ Tumor histology } & Mucinous & $1 / 3(33 \%)$ & $23(67 \%)$ & \multirow[t]{2}{*}{0.783} \\
\hline & $\begin{array}{l}\text { Non } \\
\text { mucinous }\end{array}$ & $9 / 19(47 \%)$ & $1019(53 \%)$ & \\
\hline \multirow[t]{3}{*}{ Tumor depth } & $\mathrm{T} 1$ & $2 / 5(40 \%)$ & $3 / 5(60 \%)$ & \multirow[t]{3}{*}{0.576} \\
\hline & $\mathrm{T} 2$ & $7 / 13(54 \%)$ & $6 / 13(46 \%)$ & \\
\hline & $\mathrm{T} 3$ & $1 / 4(25 \%)$ & $3 / 4(75 \%)$ & \\
\hline \multirow[t]{3}{*}{ Tumor grade } & WD & $2 / 3(67 \%)$ & $1 / 3(33 \%)$ & \multirow[t]{3}{*}{0.174} \\
\hline & MD & $5 / 9(56 \%)$ & $4 / 9(44 \%)$ & \\
\hline & PD & $3 / 10(30 \%)$ & $7 / 10(70 \%)$ & \\
\hline
\end{tabular}


Web Site: https://jmed.utq.edu.iq

Email:utjmed@utq.edu.iq

ISSN (Print):1992-92 18, ISSN (Online):1992-92 18

DOI: https://doi.org/10.32792/utq/utjmed/19/1/9

Correlation between BRCA1 and different clinicopathological parameters:

Pattern of staining was diffuse in all the cases.

Positive staining was localized in the cytoplasm in all the cases.
The quantity of BRCA1 immunostaining was +++ in $(2)$ cases while was ++ in (1) case.

Table 3: Correlation between BRCA1 expression and different clinicopathological parameters:

\begin{tabular}{|c|c|c|c|c|}
\hline \multicolumn{2}{|l|}{ The variable } & Positive BRCA1 & negative BRCA1 & P value \\
\hline \multirow[t]{3}{*}{ Groups } & Normal & 0 & $6(100 \%)$ & \multirow[t]{3}{*}{0.073} \\
\hline & Benign & $3 / 22(14 \%)$ & $19 / 22(86 \%)$ & \\
\hline & Malignant & 0 & $22(100 \%)$ & \\
\hline \multirow[t]{2}{*}{ Age } & $\geq 40$ & $1 / 23(4 \%)$ & $22 / 23(96 \%)$ & \multirow[t]{2}{*}{0.557} \\
\hline & $<40$ & $2 / 21(10 \%)$ & $19 / 21(90 \%)$ & \\
\hline \multirow[t]{2}{*}{ Sex } & Male & $2 / 26(8 \%)$ & $24 / 26(92 \%)$ & \multirow[t]{2}{*}{1.000} \\
\hline & Female & $1 / 18(6 \%)$ & $17 / 18(94 \%)$ & \\
\hline \multirow[t]{2}{*}{ Tumor site } & colon & $2 / 26(8 \%)$ & $24 / 26(92 \%)$ & \multirow[t]{2}{*}{0.687} \\
\hline & Rectum & $1 / 18(6 \%)$ & 17/18(94\%) & \\
\hline \multirow{2}{*}{$\begin{array}{l}\text { Tumor size } \\
\text { in } \mathrm{cm}\end{array}$} & $\geq 4$ & $1 / 15(7 \%)$ & $14 / 15(93 \%)$ & \\
\hline & $<4$ & $2 / 29(7 \%)$ & $27 / 29(93 \%)$ & \\
\hline
\end{tabular}

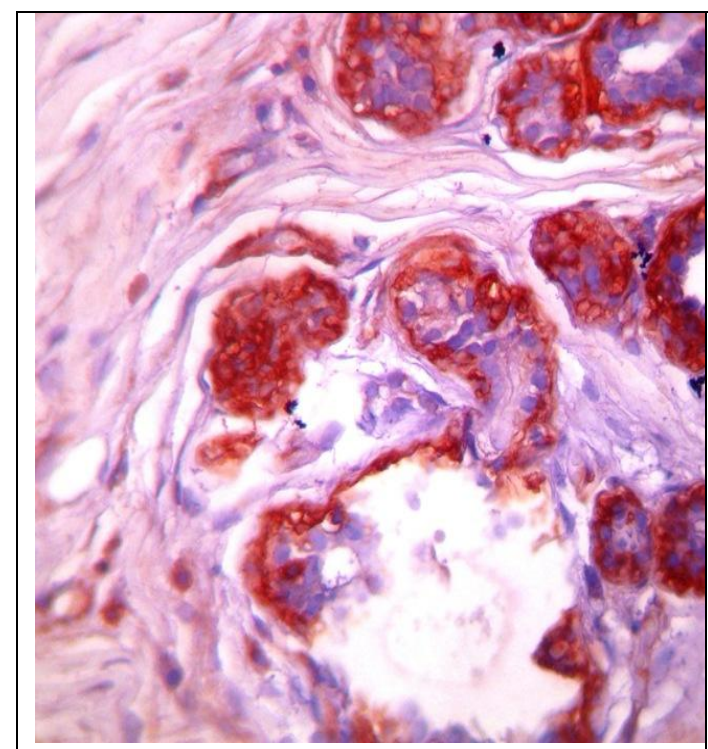

igure (1): M D CRC show strong positive HER2 Ineu expression membrane and cytoplasm (arrow) (IHC staining) $x 40$

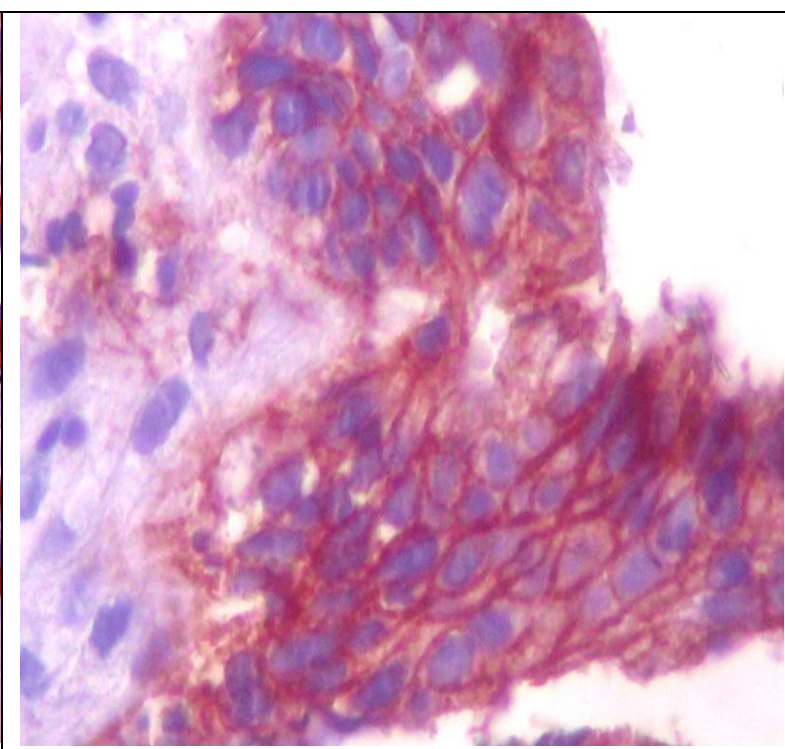

Figure (2): Well to M D CRC show strong positive HER2\neu expression membrane and cytoplasm (arrow) (IHC staining) $x 40$. 
ISSN (Print):1992-92 18, ISSN (Online):1992-92 18

DOI: https://doi.org/10.32792/utq/utjmed/19/1/9

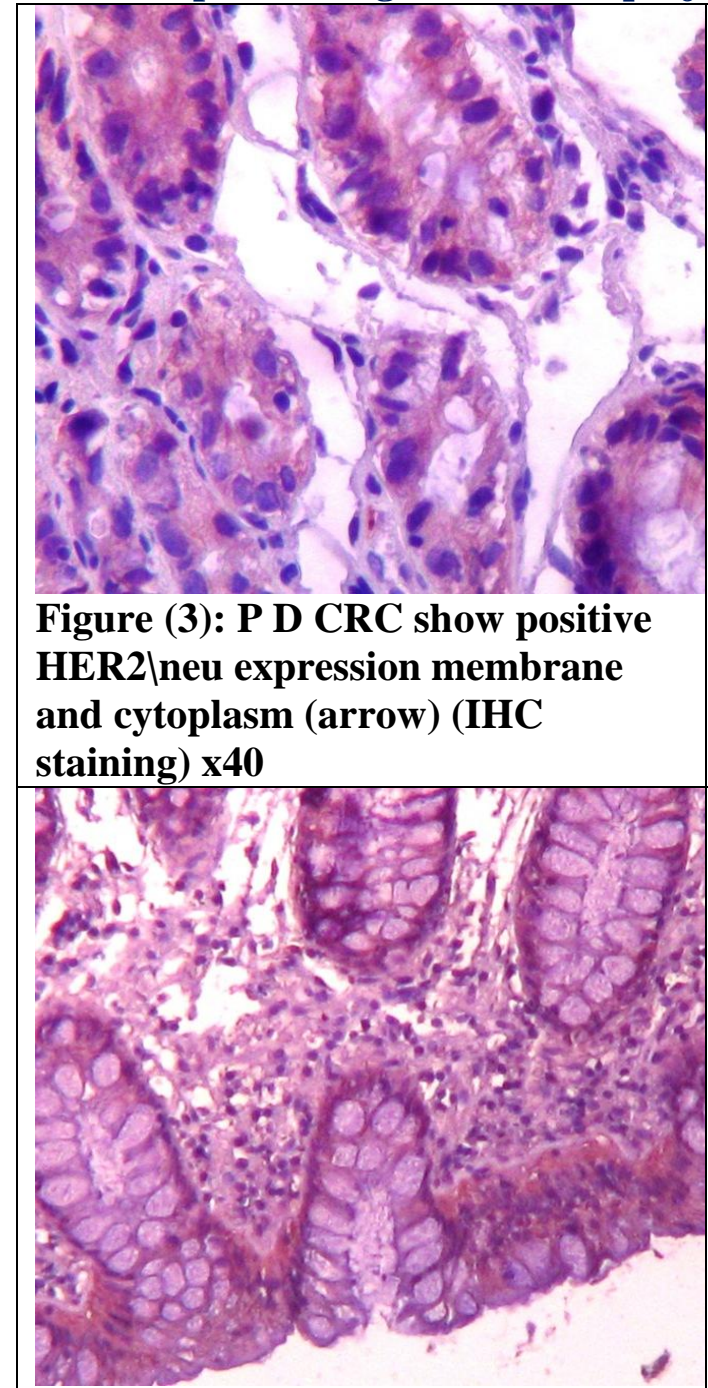

Figure (5): Mild non specific colitis (biopsy) tissue show positive HER2Ineu expression membrane and cytoplasm (arrow) (IHC staining) $x 40$.

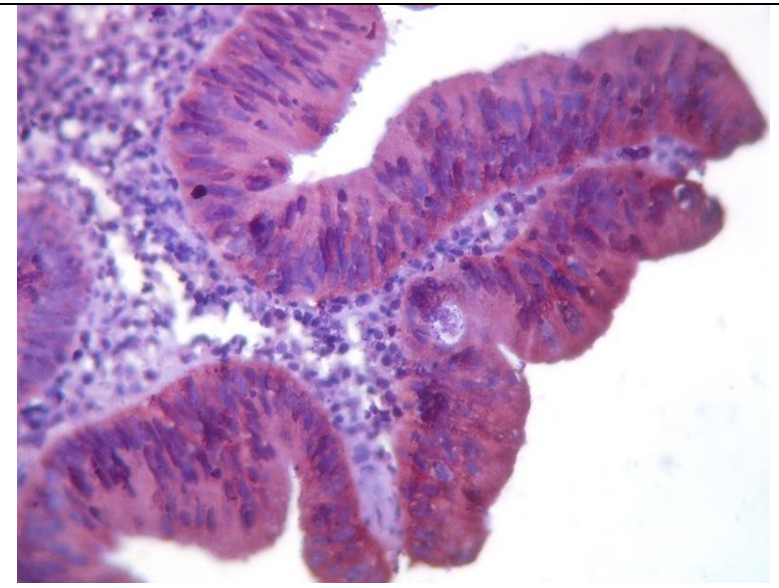

Figure (4): Villous adenoma show strong positive HER2 Ineu expression membrane and cytoplasm (arrow) (IHC staining) x40

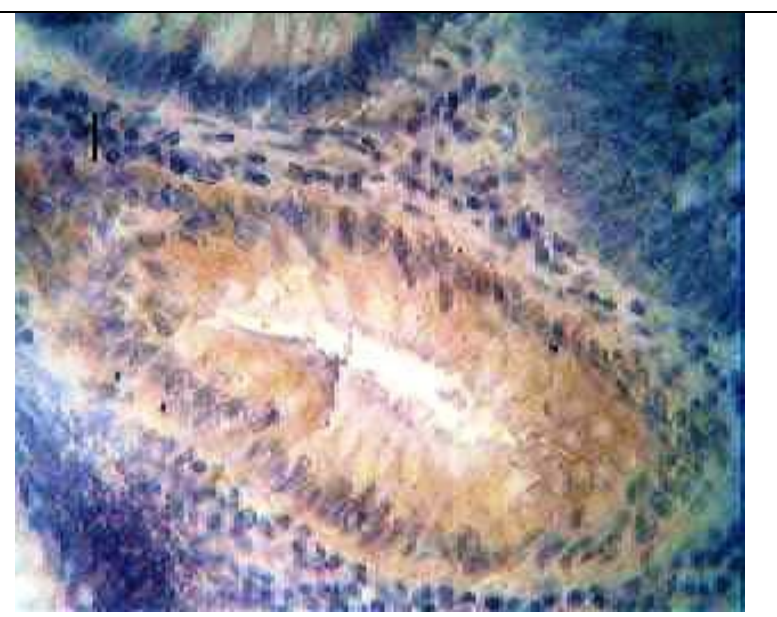

Figure (6): Tubular adenoma show positive BRCA1 cytoplasmic expression (arrow) (IHC staining) x40.

\section{Discussion:}

Clinicopathological Aspects:

The findings of the present study was revealed that high incidence of colorectal tumors in male (male :female ratio was 1.4:1 ) These results were in accordance with data from other Iraqi studies $\left.{ }^{(19,20,21}\right)$.The sex ratio in other series in Iraq and Arab countries also reported high male ratio ${ }^{(22,23,24)}$ while male to female ratio in west countries is $(1: 0.9)^{(25)}$.This finding represent difference in sex ratio between Arab and west population, although it may be a function of referral focus.

Regarding the mean age of cases in the present study was $44.42 \pm 2.53$ years for both sexes. This result was in accordance with data of Al-Bahrani, $2003^{(19)}$ in which the average age was 49.8 years for colonic and 43.4 years for rectal cancers.

Regarding the site of colorectal tumors, the colon was the most common site for colorectal tumors ( 26 cases) most of 


\section{ISSN (Print):1992-92 18, ISSN (Online):1992-92 18 DOI: https://doi.org/10.32792/utq/utjmed/19/1/9}

them (20 case) in the sigmoid, while in the rectum there were (18) cases of colorectal tumors this was in agreement with other studies ${ }^{(17,19,20)}$ in which the colon was the most common site.

To compare our results concerning the tumor grade, most of the cases were of poorly differentiated adenocarcinoma this was in agreement with some studies (26) while disagree with others $(19,20,22,23,24,27,28)$, where the moderately differentiated grade consisted most of the cases this different due to small sample size in the present study .

HER2 \neu immunoreactivity:

The pattern of staining is one of the important features of HER2 expression in colon cancer in the present study. Although there is high percent of positive staining $(36 \%$ of colorectal tumors), there is no pure membranous staining. This means that other mutations for HER2Ineu must be responsible in colon carcinoma. In the present study, HER2 \neu expression was membranous (predominant) and cytoplasm staining in most of the cases and pure cytoplasmic staining in one case .There was no case with pure membranous staining, This result matches the observations of others $(17,29,30) \quad$ who showed cytoplasmic staining or membrane and cytoplasm but no pure membrane staining while others considered only membranous staining as HER2 Ineu over expression (according to guidelines for breast cancer) ${ }^{(31,32) \text {. }}$

The percentage of the HER2 Ineu expression increased in order of adenoma (27\%) to adenocarcinoma $(45 \%)$ although the result was statistically not significant. This was in agreement with other studies ${ }^{33,34}$ who showed that the over expression of HER2 Ineu in colon polyps (adenoma) was lower than in cancer group.
HER2 \neu was expressed in $(45 \%)$ of CRC. Eliane $\mathrm{C}$ et al, $2005^{(35)}$ showed that HER2 \neu over expression was $(51 \%)$ of CRC, the expression of HER2 \neu in Irena et al, 2000 (36) study was (54\%), in Ghaffarzadegan et al,2006(17) study showed (59\%), in J A McKay et al,2002 ${ }^{(37)}$ study

(81.8\%)of CRC, in Schuell B et al,2006 ${ }^{(38)}$ study (30\%) of CRC , in Nathanson et al,2005 ${ }^{(39)}$ study only in $(3.6 \%)$ of the cases and in Park et al,2004 ${ }^{(40}$ ) study found that HER2Ineu over expression in $(12.5 \%)$ of patients, these differences were due to difference in sample size in each study and different staining pattern in the last two studies.

HER2 \neu was over expressed in $(27 \%)$ of colonic polyps Marek et al, $2009^{(34)}$ was showed that HER2।neu over expression was found in $(43 \%)$ of colorectal polyps and Irena et al, $2000^{(36)}$ was showed that HER2।neu over expression in $(87 \%)$ of colonic polyps.

Regarding the site of colorectal tumors,HER2 2 neu was more frequently expressed in the colon (46\%) while its expression in rectal tumors was $(22 \%)$.The result was statistically not significant. This result was in agreement with other studies (17,37).

Regarding the age and sex of patients, HER2 \neu expression was found to be more frequently among females (39\%) and patients of an age group more than 40 years (43\%) although the result was statistically not significant. This was in agreement with other studies ${ }^{(17,37.38,41)}$, HER2 2neu was more frequently Expressed in well differentiated adenocarcinoma (67\%). This result was in agreement with other studies $(17,37,38,39.41)$

Regarding HER2 \neu expression in colorectal polyps in the present study, 


\section{ISSN (Print):1992-92 18, ISSN (Online):1992-92 18 DOI: https://doi.org/10.32792/utq/utjmed/19/1/9}

it was expressed most frequently in tubulovillous adenomatous polyps $(50 \%)$. This is in agreement with the result of some studies ${ }^{(36)}$ but not with others ${ }^{(41)}$ which showed that there is no HER2 \neu expression in colorectal polyps.

HER2 Ineu was expressed highly in nonmucinous type $(47 \%)$ as compared with the mucinous type of CRC (33\%). This was in agreement with other studies ${ }^{(17,}$ 41).

HER2 \neu expression was higher in tumors size of more than $4 \mathrm{~cm}$. The result was statistically not significant. This result was in agreement with others $(37,38,41)$.

HER2 \neu expression was observe in (4) out of (6) non neoplastic colonic tissue which were cases of mild non specific colitis. Galandiuk s, $1993^{(42)}$ showed that there was high HER2।neu expression in non neoplastic colonic tissues (normal colonic tissues, non specific colitis, Crohn's colitis and ulcerative colitis) and J A McKay et al,2002 ${ }^{(37)}$ showed that HER2 \neu expression in normal colonic tissue was in high percent, Wen Jin et al,2004 (43) show that the levels of HER2 \neu were obviously increased in normal colonic tissue and adenoma.

In addition to other studies, Ross et al, $2001^{(44)}$ studied the HER2Ineu oncogene in tumors of the gastrointestinal tract. They found wide range of HER2/neu expression in Esophageal, gastric and colon carcinoma. They concluded that either HER2protein overexpression or gene amplifications associated with one - forth of all gastrointestinal malignancies and strategies designed to employ the marker in therapy selection appear warranted ${ }^{(44)}$.

BRCA1 immunoreactivity:-

BRCA1 expression was found in $(6 \%)$ of the cases of colorectal tumors (benign and malignant), there were (14\%) positive cases of colorectal polyps. There was non significant correlation between BRCA1expression and types of tumors (benign or malignant).

Garcia-Pati et al, $1998^{(63)}$ showed that BRCA1 was expressed in $(49 \%)$ of colorectal tumor this difference may be explained by small sample size in the present study.

BRCA1 expression was more frequently in males patients $(8 \%)$ than in females patients $(6 \%)$ although the results were statistically not significant. This was in agreement with others $(18,46)$

BRCA1expression was more in age group more than 40 years old $(10 \%)$ although the result was statistically not significant. This in agreement with other studies, ${ }^{(18,46)}$.

There was no difference in BRCA1 expression between tumors with size of more than or less than $4 \mathrm{~cm}$. This result was in agreement with other studies ${ }^{(18,}$ 46) that also showed no significant correlation of BRCA1 expression with tumors size.

BRCA1expression was more frequently observed in the colon $(20 \%)$ than in the rectum $(8 \%)$ although the result was statistically not significant.This was in agreement with other $^{(18)}$.

BRCA1 expressed in (1) out of (2) tubulovillous adenomatous polyps, in (1) out of (3) villous adenoma and in (1) out of (8) tubular adenoma. Ishiguro $\mathrm{K}$ et al, $2006^{(47)}$ showed that there was BRCA1 expression in $13 \%$ of colorectal tubular adenomas, $53 \%$ of villous adenomas so they reached to conclusion from this study that the presence of genetic alterations in stroma form an early stage of carcinogenesis, accompanied by stepwise increasing genetic instability of epithelia with progression to cancer. Thus microenvironmental changes due to genetic alteration in Chr17 markers in 


\section{ISSN (Print):1992-92 18, ISSN (Online):1992-92 18 DOI: https://doi.org/10.32792/utq/utjmed/19/1/9}

stromal cells may play an important role in colon adenoma and adenocarcinoma development, BRCA1 genes on chromosome 17(Chr17) my play an important role in adenoma carcinoma sequence.

There was no BRCA1 expression in colorectal adenocarcinoma in the present study while Heike Grabsch et al, 2006 ${ }^{(18)}$ showed that BRCA1 was expressed in $(86 \%)$ of colorectal adenocarcinoma. This difference between this study and the present study may be explained by small sample size in the present study .

\section{References:}

1. World Health Organization. February 2014. Retrieved 24 May 2015.

2.National Cancer Institute. 2014.

3.Report of Iraq Cancer Registry, Ministry of health, Baghdad- Iraq, 2012.

4.Baselga J, Mendelsohn J: The epidermal growth factor receptor as a target for therapy in breast carcinoma. Breast Cancer Res Treat 1994, 29:127-138.

5.Garcia JM, Rodriguez R, Dominguez G. Prognostic significance of the allelic loss of the BRCA1gene in colorectal cancer. Gut 2003; 52:1756-63.

6. Berczi C; Bocsi J.; Bartha I.; Math J.; Balazs G.: Prognostic value of DNA ploidy status in patients with rectal cancer. Anticancer Res. 2002; 22(68):3737-41.

7.Slamon DJ, Clark GM. Amplification of C-ERB-B2 and aggressive breast tumors. Science 1988; 240: 1795-1798.

8.Vogel CL, Cobleigh MA, Tripathy D, Gutheil JC, Harris LN, Fehrenbacher L, Salamon DJ, Murphy M, Novotny WF, Burchmore M, Shak S, Stewart SJ et, Press M: Efficacy and safety of trastuzumab as a single agent in first-line treatment of HER2-overexpressing metastatic breast cancer J Clin Oncol 2000; 20:719-26.

9.Mann M, Sheng H, Shao J, Williams CS, Pisacane PI, Sliwkowski MX, DuBois RN: Targeting cyclooxygenase 2 and HER-2/neu pathways inhibits colorectal carcinoma growth. Gastroenterology 2001; 120:1713-9.

10.Hall J, Lee M, Newman B, Morro J, Anderson L, Huey B, Linkage of early onset familial breast cancer to chromosome 17q21. Science, 1990, 250: 1684-9.

11.Futreal P A, Soderkvisi P, Marks J R, Iglehart J D, Cochran C, Barrett J C and Wiseman R W. Detection of frequent allelic loss on proximal $17 \mathrm{q}$ in sporadic breast carcinoma using microsatellite length polymorphisms; Cancer Res. 1992, 52 26242627.

12.Rahman N, Stratton MR: The genetics of breast cancer susceptibility. Annu Rev Genet 1998; 32:95-121. 
Thi-Qar Medical Journal (TQMJ): Vol.(19), No.(1), 2020

Web Site: https://jmed.utq.edu.iq

Email:utjmed@utq.edu.iq

ISSN (Print):1992-92 18, ISSN (Online):1992-92 18

DOI: https://doi.org/10.32792/utq/utjmed/19/1/9

13.Brose MS, Rebbeck TR, Calzone KA.: Cancer risk estimates for BRCA1 mutation carriers identified in a risk evaluation program. J Nat Cancer Inst 2002; 94 (18): 1365 72 .

14.Thompson D and Easton DF; Breast Cancer Linkage Consortium.: Cancer Incidence in BRCA1 mutation carriers. J Nat Cancer Inst 2002; 94 (18): 1358-65.

15.Brose MS, RebbeckTR, Calzone KA. Cancer risk estimates for BRCA1mutation carriers identified in a risk evaluation program. J Nat 1 Cancer Inst 2002; 94:1365 72.

16. Galandiuk S, Miseljic S, Yang AR, Early M, McCoy MD, Wittliff JL. Expression of hormone receptors, cathepsin D, and HER-2/neu oncoprotein in normal colon and colonic disease. Arch Surg. 1993 Jun;128(6):637-642.

17. Ghaffarzadegan K., Sharifi N., Vosooghynia H., Shakeri T., Ghiasi T. Moghadam,Sh. Ghanad Kafi, Lari S., Nassiri. G.; HER2/neu expression in colon adenocarcinoma and its correlation with clinicopathologic variables. 2006;20:66-80.

18,Heike Grabsch, Mit Dattani, Lisa Barker,NicolaMaughan,KarenMaude,Olaf Hansen,Helmut E. Gabbert, Phil Quirke, and WolframMueller. Expression of DNA Double-Strand Break Repair Proteins ATM and BRCA1Predicts Survival in Colorectal Cancer. Clin Cancer Res 2006; 12(5).

19. A1-Bahrani ZR , Al Hadithi RH , Al Bahrani AZ . Colorectal carcinoma In Iraq: Clinicopathological study. The Arab JG, October 2003;4 :104-110.

20. Al-Humadi.A H. Epidemiology of Colon \& Rectal Cancer In Iraq, World Journal of Colorectal Surgery2008;15:20-22

21. Naim H. Expression of B-HCG and its pathological Aspect in Colorectal carcinoma .A thesis submitted to the scientific council of pathology as a partial fulfillment of the requirement for the degree of board in pathology 2005

22. Kakill R, Abdullah SA, Ahmed AM \& Ussama M. study of colorectal cancer in Qatar. Saudi Med J 2001; 22(8): 705-707.

23.Isbister WH. Malignant neoplasm of colon, rectum and anus at the king Faisal specialist Hospital \& Research centre. Ann Saudi/ Med 1992; 12 (5): 429-433.

24.Ibrahim M, Ibrahim HZ \& Syed AR. Colorectal cancer in Saudi Arabia. Saudi Med J, 2002; 33:322-326.

25.Isbister WH \& Fraser J. Survival following resection for colorectal cancer. Dis colon rectum $1985 ; 28: 725-72$. 
ISSN (Print):1992-92 18, ISSN (Online):1992-92 18

DOI: https://doi.org/10.32792/utq/utjmed/19/1/9

26.H. Darwish, I. E. Trejo, I. Shapira, S. Oweineh, M. Sughayer, L. Baron, E. Aljadeff,M. colorectal cancer: molecular epidemiology differences among Ashkenazi and Sephardic Jews and Palestinians. Annals of Oncology 2002;13: 1497-1501

27.Berczi C; Bocsi J.; Bartha I.; Math J.; Balazs G.: Prognostic value of DNA ploidy status in patients with rectal cancer. Anticancer Res. 2002; 22(68):3737-41

28.Kathryn LS, Michael JS, and Danel R. Review of colorectal cancer in patients under age 40 years. Am J Surg, 1981; 142:767-769.

29.Half E., Broaddus R., Danenberg K. D., Danenberg P. V., Ayers G. D., Sinicrope F. A. HER2 receptor expression, localization , and activation in colorectal cancer cell lines and human tumors, Int. J. Cancer 2004; 108: 540-8.

30.Toshikatsu Osako, Masaki Miyahara, Shinya Uchino, Masafumi Inomata, Seigo Kitano, Michio Kobayashi. Immunohistochemical Study of c-erbB-2 Protein in Colorectal Cancer and the Correlation with Patient Survival.: 1998; 55:548-555.

31.Nathanson DR, Culliford AT 4th, Shia J, Chen B, D'Alessio M, Zeng ZS, Nash GM, Gerald W, Barany F, Paty PB.: HER 2/neu expression and gene amplification in colon cancer. Int J Cancer. 2003 Jul 20; 105(6):796-802.

32.Park D. I., Oh S. J., Park S. H., Yun J. W. Clinical significance of HER-2/neu expression in colon cancer, Korean J. Gastroenterol. 2004; 44:147-52.

33.Wen Jin, Mei-Qin Gao, Zhi-Wu Lin, Dai-Xing Yang. Quantitative study of multiple biomarkers of colorectal tumor with diagnostic discrimination model. World J Gastroenterol 2004; 10(3):439-442.

34.Marek Pazurek, Beata Smolarz, Hanna Romanowicz-Makowska, Andrzej Kulig, Ewa Małecka-Panas.: Overexpression of HER-2/neu in patients with colorectal cancer (CC) and colorectal adenomas (CP) 2009; 50(3):179-182.

35.Eliane C. Jesus; Delcio Matos; Ricardo Artigiani; Angela F.L. Waitzberg; Alberto Goldenberg; Sarhan Sydney Saad. Assessment of staging, prognosis and mortality of colorectal cancer by tumor markers: receptor erbB-2 and cadherins.: Nov./Dec. 2005; 0102-8650.

36.Irena Porebska, Antonina Haroziska, Tomasz Bojarowski.: Expression of the Tyrosine Kinase Activity Growth Factor Receptors (EGFR, ERB B2, ERB B3) in Colorectal Adenocarcinomas and Adenomas. Tumor Biol 2000; 21:105-115.

37.McKay J. A., Loane J. F., Ross V. G., et al. C-erbB2 is not a major factor in the development of colorectal cancer, Br. J. Cancer 2002; 86: 568-73.

38.SchuellB,Gruenberger,Scheisauer,Zielinski,Wrba.: HER 2/neu protein expression in colorectal cancer. BMC CANCER 2006 May; 8;6:123 
Thi-Qar Medical Journal (TQMJ): Vol.(19), No.(1), 2020

Web Site: https://jmed.utq.edu.iq

Email:utjmed@utq.edu.iq

ISSN (Print):1992-92 18, ISSN (Online):1992-92 18

DOI: https://doi.org/10.32792/utq/utjmed/19/1/9

39.Nathanson DR, Culliford AT 4th, Shia J, Chen B, D'Alessio M, Zeng ZS, Nash GM, Gerald W, Barany F, Paty PB.: HER 2/neu expression and gene amplification in colon cancer. Int J Cancer. 2003 Jul 20; 105(6):796-802.

40.Park D. I., Oh S. J., Park S. H., Yun J. W. Clinical significance of HER-2/neu expression in colon cancer, Korean J. Gastroenterol. 2004; 44:147-52

41.Aylar Poyraz, Ozlem Suer, Cem Sezer and Gulen Akyol.: Expression of Bcl-2 and c-ErbB-2 in colorectal neoplasia. February 28, 2009; 7: 24-27.

42.Galandiuk S, Miseljic S, Yang AR, Early M, McCoy MD, Wittliff JL. Expression of hormone receptors, cathepsin D, and HER-2/neu oncoprotein in normal colon and colonic disease. Arch Surg. 1993 Jun;128(6):637-642.

43.Wen Jin, Mei-Qin Gao, Zhi-Wu Lin, Dai-Xing Yang. Quantitative study of multiple biomarkers of colorectal tumor with diagnostic discrimination model. World J Gastroenterol 2004; 10(3):439-442.

44.Ross J. S., McKenna. TheHER-2/neu oncogene in tumors of the gastrointestinal tract, Cancer Invest 2001; 19: 554-68.

45.Garcia-Patio E, Gomendio B, Lleonart M, Silva JM, Garcia JM, Provencio M, Cubedo R, Espaa P, Ramn y Cajal S, Bonilla . Loss of heterozygosity in the region including the BRCA1 gene on 17q in colon cancer. Cancer Genet Cytogenet. 1998 Jul $15 ; 104(2): 119-23$.

46.Bethany L. Niell, Gad Rennert, Joseph D. Bonner, Stephen B. Gruber. RESPONSE: Re: BRCA1 and BRCA2 Founder Mutations and the Risk of Colorectal Cancer (2004): 96(15):1185-1186

47.K Ishiguro, T Yoshida, H Yagishita, Y Numata, and T Okayasu. Epithelial and stromal genetic instability contributes to genesis of colorectal adenomas.2006 May; 55(5): 695-702. 


\section{استظهار عامل HER2 \NEU و BRCA1 في أورام القولون والمستقيم وعلاقته بالخصائص المرضية لدراسة مرضية أوضية

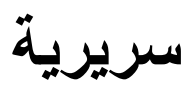

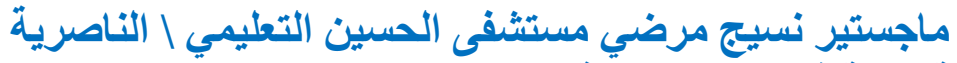

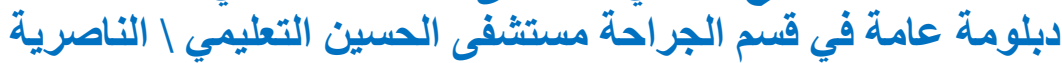

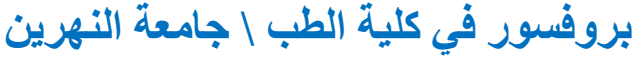

د.سارة سعد بنيان د.عقيل سعد بنيان

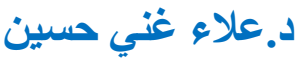

الناخلاصة

خُلقية البحث: يعد سرطان القولون من السرطانات الثائعة وخاصة في العراق .لقد اضهرت

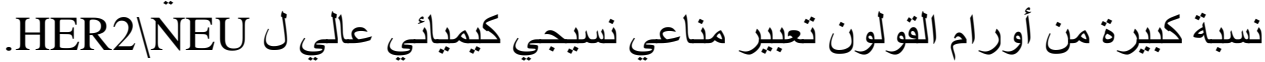

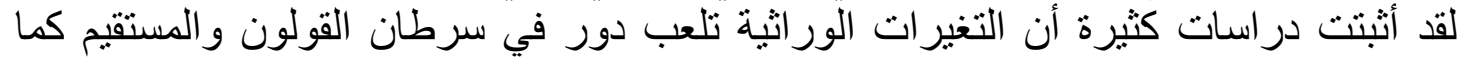

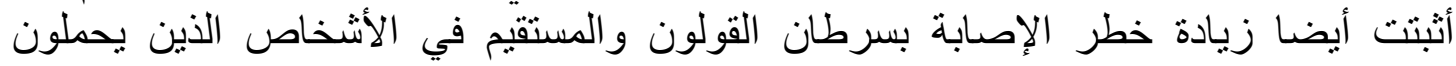

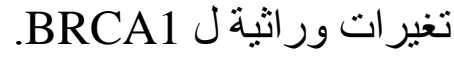

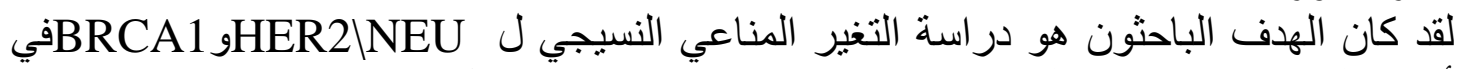

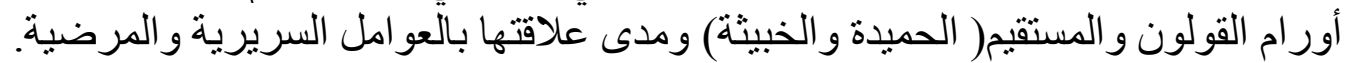

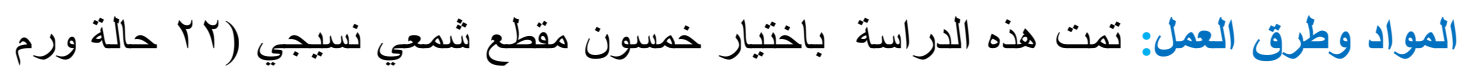

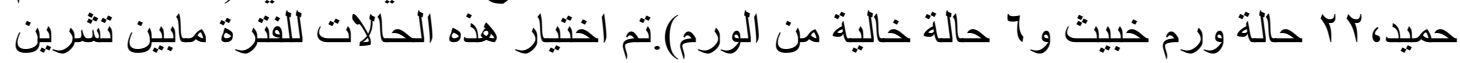

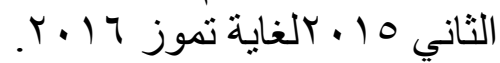
تم تقطيع هذه المقاطع الثمعية وصبغها بصبغة الهيماتوكسلين والايوسين ثم استعمالها لمعرفة

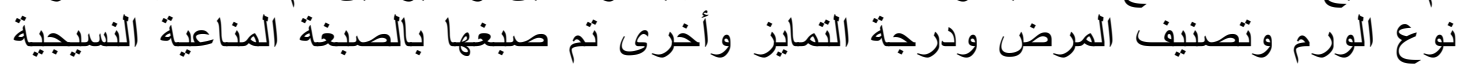

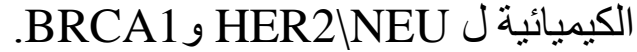
لقد كان التعبير المناعي HER2INEU ظاهر ا في الغلاف الخلوي او السايتو بلازم أو كالاهما

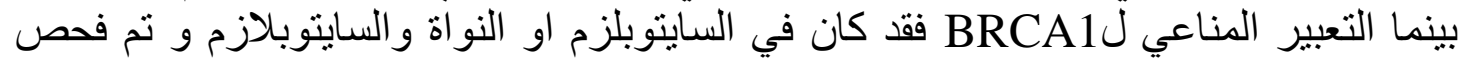
المقاطع المصبوغة بهذه الصبغات المناعية كونها سالبة أو موجبة فئة

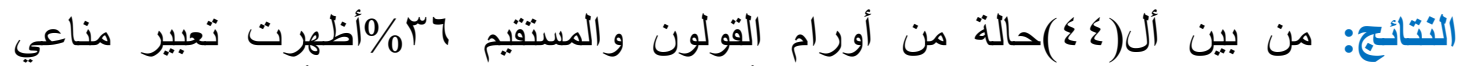

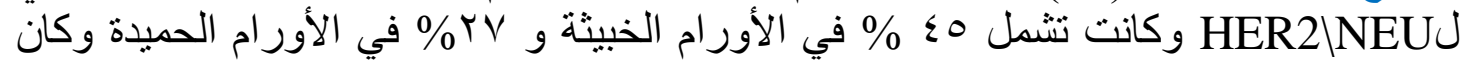
هذا التعبير أكثر في الذكور.

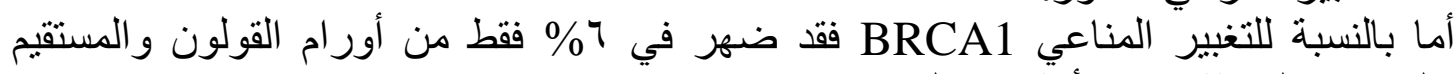
(الحميدة و الخبيثة) وكان أكثر في الذكور •

الاستنتاجات: أن تعبير ألHER2\NEU في أورام القولون والمستقيم ليس بقليل جس\%

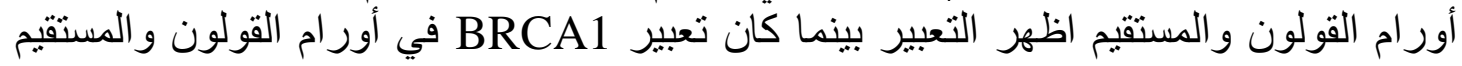
قليلا 7\% فقط اظهر التعبير. 